\title{
Increased expression of transforming growth factor $\alpha$ precursors in acute experimental colitis in
} rats

P Hoffmann, J M Zeeh, J Lakshmanan, V S Wu, F Procaccino, M Reinshagen, J A McRoberts, V E Eysselein

\begin{abstract}
Background and aim-Epidermal growth factor (EGF) and transforming growth factor $\alpha(T G F-\alpha)$, members of the EGF family of growth factors, protect rat gastric and colonic mucosa against injury. Having shown previously that exogenously applied EGF protects rat colonic mucosa against injury, the aim of the present study was to evaluate the endogenously expressed ligand mediating the protective effect of EGF/TGF- $\alpha$ in vivo.

Methods-In an experimental model of trinitrobenzene sulphonic acid (TNBS)/ ethanol induced colitis in rats EGF and TGF- $\alpha$ expression was evaluated using a ribonuclease protection assay, northern blot analysis, western blot analysis, and immunohistochemistry.

Results-TGF- $\alpha$ mRNA increased 3-4 times at 4-8 hours after induction of colitis and returned to control levels within 24 hours. TGF- $\alpha$ immunoreactive protein with a molecular size of about $28 \mathrm{kDa}$ representing TGF- $\alpha$ precursors increased markedly after induction of colitis with a peak at 8-12 hours. No fully processed 5.6 kDa TGF- $\alpha$ protein was detected in normal or inflamed colon tissue. Only a weak signal for EGF mRNA expression was detected in the rat colon and no EGF protein was observed by immunohistochemistry or western blot analysis.

Conclusions-TGF- $\alpha$ precursors are the main ligands for the EGF receptor in acute colitis. It is hypothesised that TGF- $\alpha$ precursors convey the biological activity of endogenous TGF- $\alpha$ peptides during mucosal defence and repair.

(Gut 1997; 41: 195-202)
\end{abstract}

Keywords: transforming growth factor alpha (TGF- $\alpha$ ); epidermal growth factor (EGF); precursor molecules; colitis; rat

The epidermal growth factor (EGF) family consists of several peptide hormones which share the ability to bind to a common receptor. ${ }^{1-4}$ Among the members of the EGF family, EGF and transforming growth factor alpha (TGF- $\alpha$ ) have been studied extensively and both were identified previously in the human $^{56}$ and rat gastrointestinal tract. ${ }^{6-8} \mathrm{EGF}$ was first isolated from mouse submandibular glands as a 53 amino acid peptide ${ }^{1}$ and TGF- $\alpha$ was first isolated from the medium of retrovirus-transformed fibroblasts ${ }^{4}$ as a 50 amino acid peptide. TGF- $\alpha$ shares a $30 \%$ homology with EGF. ${ }^{9}$ Both EGF and TGF- $\alpha$ are synthesised as large membrane anchored precursors. The EGF precursor has a molecular weight of $150-180 \mathrm{kDa}^{10}$ while TGF- $\alpha$ precursors are smaller with molecular weights between 18 and $68 \mathrm{kDa} .{ }^{11}{ }^{12}$ Size heterogeneity of the TGF- $\alpha$ species results from differential proteolytic cleavage and $\mathrm{N}$ - and O-glycosylation. ${ }^{11}{ }^{13}{ }^{14}$ Although enzymes responsible for proteolytic processing of TGF- $\alpha$ precursors in vivo are unknown, the mature 50 amino acid TGF- $\alpha$ peptide can be enzymatically cleaved in vitro from the precursor molecule by elastase. ${ }^{14}$ Both EGF and TGF- $\alpha$ membrane anchored and soluble precursor molecules are able to bind and activate the EGF receptor. ${ }^{10}{ }^{15}$ The membrane anchored TGF- $\alpha$ precursor has been shown to interact with EGF receptors on adjacent cells in vitro. ${ }^{15}$

EGF and TGF- $\alpha$ are potent mitogens for certain types of cells of the gastrointestinal tract in vitro ${ }^{1}$ and in vivo. ${ }^{16}$ Besides their mitogenic effects, members of the EGF family of growth factors are able to modulate cell migration, ${ }^{17}$ mucosal blood flow, ${ }^{18}$ gastrointestinal motility, ${ }^{19}$ mucus production and secretion, ${ }^{20}$ and gastric acid secretion. ${ }^{21}$

TGF- $\alpha$ mRNA and immunoreactive peptide have been identified in human and rat colonic mucosa, ${ }^{568}$ and EGF immunoreactivity has been detected in human and rat colon. ${ }^{57}$ In patients with Crohn's disease expression of EGF immunoreactivity has been described around colonic ulcers. ${ }^{22}$

The role of the EGF family of peptides in mucosal defence and repair after injury of the colon is currently under investigation. Using an experimental model of colitis in the rat, we have shown that EGF given exogenously prior to the induction of colitis protects the colonic mucosa. ${ }^{23}$ These results indicate that the EGF family of peptides plays an important part in mucosal protection in the early phase of colitis.

The aim of our present study was to determine the endogenously expressed ligand for the EGF receptor in the early phase after colonic injury using the same animal model of colitis.

\section{Methods}

EXPERIMENTAL DESIGN

Male Sprague-Dawley rats with body weights of 250-300 g were fasted overnight with free 
access to drinking water. Animals were given $50 \mathrm{mg} / \mathrm{kg}$ trinitrobenzene sulphonic acid (TNBS) in $50 \%$ ethanol as enemas to induce colitis as described previously. ${ }^{23}$ Three animals were sacrificed before and at 2, 4, 8, 12, and 24 hours after induction of colitis. Representative colonic tissues were processed for evaluations of histological tissue damage, myeloperoxidase activity, and TGF- $\alpha$ and EGF expression.

Evaluation of histological tissue damage

Specimens were fixed in zinc formalin, embedded in paraffin wax blocks, cut in $6 \mu \mathrm{m}$ thick sections, and consecutively stained with haematoxylin and eosin. The extent of tissue damage was evaluated microscopically and macroscopically as percentage oedema, erosions, and ulcers as described previously. ${ }^{23}$

\section{Myeloperoxidase assay}

Tissues were homogenised in $0.5 \%$ hexadecyltrimethylammonium bromide (Sigma, St Louis, Missouri, USA). Myeloperoxidase activity was measured photometrically as changes at $470 \mathrm{~nm}$ after adding the substrate peroxide and compared with a standard dilution with horseradish peroxidase. Protein contents were estimated by the Biuret method and myeloperoxidase activity was expressed as $\mathrm{U} / \mathrm{mg}$ protein. ${ }^{24}$

Preparation of rat TGF- $a, E G F, \beta$-actin, and $18 S$ probes

Rat EGF and TGF- $\alpha$ cDNA fragments were obtained by reverse transcription and polymerase chain reaction (RT-PCR). Sense and antisense primers were designed and synthesised based on the published sequences. ${ }^{25}{ }^{26}$ Rat submandibular gland and liver total RNA were prepared and used as templates to generate a 430 bp EGF and a 156 bp TGF- $\alpha$ cDNA by RT-PCR, respectively. Both cDNA fragments were subcloned into plasmid pBlueScript II and multiple positive clones were sequenced from both directions to ensure no PCR infidelity.

EGF primers: sense 5'TGGAAAAGATGGCTGCCACTGGGTC and antisense 5'GTGTTCCTCTAGGACCACAAACCA.

TGF- $\alpha$ primers: sense 5'GCAGTGGTGTCTCACTTCAA and antisense 5'CACTGCCAGGAGATCTGCATGCTC.

Rat $\beta$-actin was donated by Dr D Cooper, Harbor UCLA Medical Center, Division of Pulmonology, and human $18 \mathrm{~S}$ cDNA probe was donated by Dr T M Gress, University of Ulm, Germany.

Plasmids containing TGF- $\alpha$, EGF or $\beta$-actin inserts were linearised by appropriate restriction enzymes and incubated with appropriate RNA polymerase in transcription buffer containing ${ }^{32} \mathrm{P}-\mathrm{UTP}$ (ICN, Biomedicals Inc, Costa Mesa, California, USA) using a standard in vitro transcription procedure (Promega, Madison, Wisconsin, USA). The human $18 \mathrm{~S}$ cDNA probe was excised with EcoR1 and random labelled using ${ }^{32}$ P-CTP (Pharmacia, Piscataway, New Jersey, USA). Final cRNA and cDNA products were extracted by phenolchloroform and precipitated with alcohol to remove unincorporated radioactive UTP.
Preparation of total cellular $R N A$ and poly- $A$ RNA

Total cellular RNA was extracted by the acidic guanidium thiocyanate method as described previously. ${ }^{27}$ In order to purify poly-A RNA biotinylated oligo(dT) was annealed in solution to mRNA and the hybrids were captured with streptavidin-coated paramagnetic particles in a magnetic separation stand (PolyATract, Promega, Madison, Wisconsin, USA).

\section{Ribonuclease protection assay}

Nuclease protection assays were performed as described previously ${ }^{28}$ and were used to quantitate the TGF- $\alpha$ and EGF mRNA before and after induction of colitis. Samples containing $15 \mu \mathrm{g}$ total RNA were annealed with $1-2 \times 10^{6}$ disintegrations per minute (dpm) of labelled probe for 16 hours at $45^{\circ} \mathrm{C}$ in buffer containing $80 \%$ formamide. After sequential digestion of hybrids with ribonucleases $\mathrm{A}$ and T1 (Boehringer Mannheim, Indianapolis, Indiana, USA) and proteinase $\mathrm{K}$ (Boehringer Mannheim) the RNA was extracted with phenol-chloroform, precipitated with 2.5 volumes of ethanol, washed with $70 \%$ ethanol, and dissolved in $99 \%$ formamide and sequencing dye. After heating for three minutes at $90^{\circ} \mathrm{C}$ the samples were briefly cooled on ice and applied to a $8 \%$ acrylamide in $8.3 \mathrm{M}$ urea DNA sequencing gel. After electrophoresis, the gel was dried and exposed to a Kodak XAR 5 film at $-70^{\circ} \mathrm{C}$ with a DuPont Lightening Plus intensifying screen (DuPont, Boston, Massachusetts, USA) for 3-6 days. The size of protected fragments was determined by including a DNA sequencing ladder in adjacent lanes. RNA abundance was calculated using scanning laser densitometry (BioRad, Hercules, California, USA) with the integrated area expressed as the average of five individual determinations.

\section{Northern blot analysis}

Poly A-RNA $(2-4 \mu \mathrm{g})$ was electrophoresed in a $1 \%$ formaldehyde agarose gel and transferred to a nitrocellulose membrane (ICN, Biomedicals Inc, Costa Mesa, California, USA). Membranes were prehybridised in $7 \%$ sodium dodecyl sulphate (SDS), 1 mM EDTA $\mathrm{pH} 8$, $1 \%$ bovine serum albumin (BSA) in $0.5 \mathrm{M}$ sodium phosphate, $\mathrm{pH} 7.2$, containing $100 \mu \mathrm{g} /$ $\mathrm{ml}$ denatured salmon sperm DNA for one hour. After prehybridisation either denatured EGF or TGF- $\alpha$ cRNA or $18 \mathrm{~S}$ cDNA probes were added $\left(10^{6}-10^{7} \mathrm{cpm} / \mathrm{ml}\right.$ hybridisation solution) and membranes were hybridised overnight. After hybridisation membranes were washed in $0.5 \times$ sodium chloride, sodium citrate (SSC) and $0.1 \%$ SDS at room temperature and $x$-ray films were then exposed for two to four days using intensifying screens at $-70^{\circ} \mathrm{C}$.

\section{Antibodies used for western blotting and immunohistochemistry}

Both a monoclonal antibody raised against the amino acid sequence $34-50$ of the fully processed $5.6 \mathrm{kDa}$ human $\mathrm{TGF}-\alpha$ peptide (Oncogene, New York, USA) that cross reacts with rat TGF- $\alpha$ and a polyclonal antibody 
(Pro-Hormone Science, Los Angeles, California, USA) raised against rat TGF- $\alpha$ were used for immunohistochemical analysis. The polyclonal antibody was used in western blot analysis. A polyclonal antibody raised against rat EGF (Pro-Hormone Science) was used to perform immunohistochemical analysis. The polyclonal TGF- $\alpha$ antibody did not cross react with EGF on western blot analysis. No cross reaction of TGF- $\alpha$ antibodies with EGF was observed in immunostaining of rat submandibular glands. The rat EGF antibody stained the submandibular gland intensively (data not shown).

\section{Immunohistochemistry}

Intact colonic rings were fixed overnight in Zamboni's solution, ${ }^{29}$ washed in $0.1 \mathrm{M}$ phosphate buffered saline (PBS), pH 7.5, containing $25 \%$ sucrose for cryoprotection, and then frozen in OCT compound. Sections $12 \mu \mathrm{m}$ thick were cut using a cryomicrotome. Immunohistochemical analysis was performed using the $\mathrm{ABC}$ technique as described previously. ${ }^{30}$ In brief, on the day of the assay sections were allowed to thaw and were washed in $0.1 \mathrm{M}$ PBS containing $0.3 \%$ Triton-X 100 . Tissues were incubated with normal goat serum $30 \%$ in 0.1 M PBS $\mathrm{v} / \mathrm{v}$ ) and incubated either with the polyclonal $(1: 750)$ or with the monoclonal (1:50) TGF- $\alpha$ antibody or with the polyclonal rat EGF antibody (1:750) for 12-15 hours at $4^{\circ} \mathrm{C}$. After washing the sections in $0.1 \mathrm{M} \mathrm{PBS} /$ $0.3 \%$ Triton-X 100 , tissue sections were incubated with secondary antibody (goat antirabbit IgG or goat anti-mouse) for two hours at room temperature. Endogenous peroxidase was quenched in ice cold methanol with $1 \%$ hydrogen peroxide. Binding was visualised after incubation with avidin biotin complex with hydrogen peroxide in the presence of diaminobenzidine (DAB). Sections were counterstained with haematoxylin and mounted with Permount medium. All pictures were taken with a Zeiss photomicroscope using a Kodak colour print film.

Western blot analysis

Colonic tissues were homogenised $(250 \mathrm{mg} / \mathrm{ml}$ $\mathrm{w} / \mathrm{v})$ in $20 \mathrm{mM}$ Tris- $\mathrm{HCl}$ buffer, $\mathrm{pH} 8.8$, containing EDTA (10 mM), NP-40 (0.5\%), and sodium deoxycholate $(0.5 \%)$ using a tissuemiser (Tekmar, Ohio). The homogenates were diluted 1:5 with Laemmli's electrophoretic sample buffer $^{31}$ containing $\beta$-mercaptoethanol and heated in a boiling water bath for 10 minutes. Samples were cooled, centrifuged, and aliquots equivalent to $3 \mathrm{mg}$ wet tissue were subjected to electrophoresis on a $15 \%$ SDS separating gel. The proteins were electrophoretically transferred to Immobilon-P membranes (Millipore, Milford, Massachusetts, USA) and immunoblotted after incubation with the polyclonal antiserum to rat TGF- $\alpha(1: 1000)$ or with the polyclonal antibody to rat EGF $(1: 1000)$. Immunoreactive bands were detected by autoradiography after labelling with ${ }^{125} \mathrm{I}$-goat anti-rabbit IgG. For reference synthetic rat TGF- $\alpha$ (Bachem, Philadelphia, Pennsylvania, USA) of known

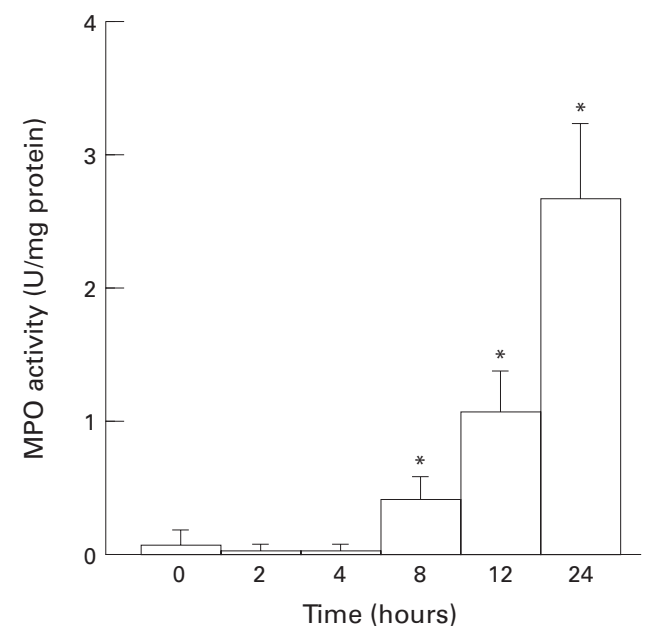

Figure 1: Myeloperoxidase (MPO) activity in U/mg protein before and up to 24 hours after induction of colitis $(n=6)$.

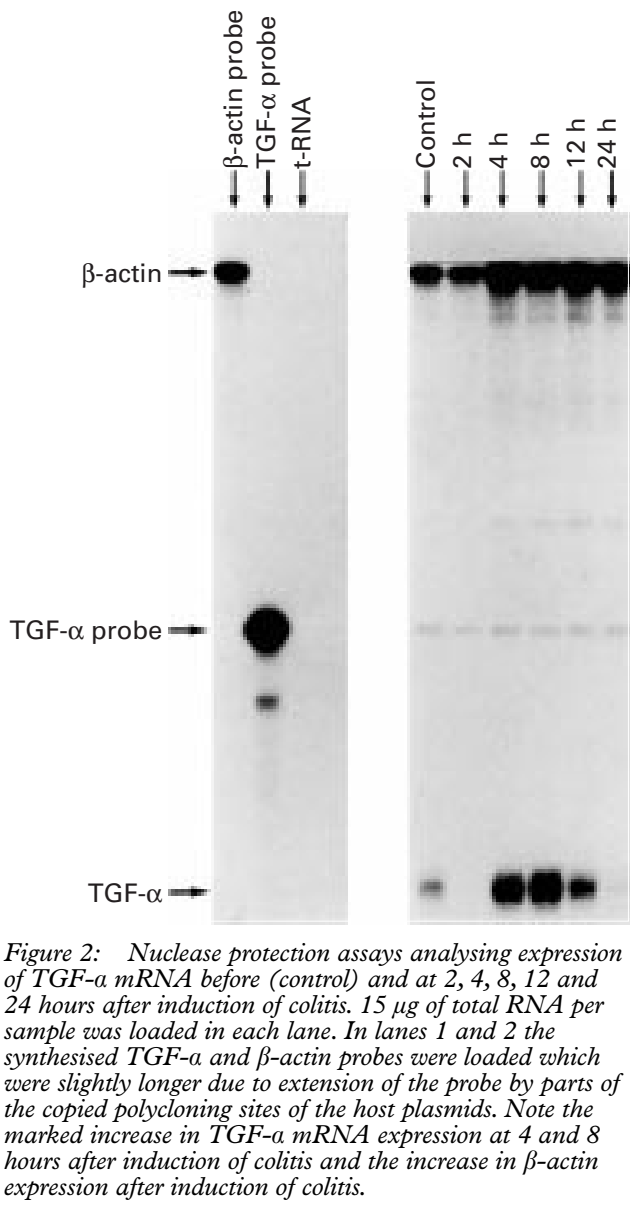

quantity was loaded in a separate lane on each gel. Non-specific binding was determined by incubating corresponding membranes either with secondary antibody alone or with different non-immune rabbit sera. Membranes were exposed to $x$-ray film for four to seven days.

\section{Statistical analysis}

The quantities of EGF, TGF- $\alpha$, and $\beta$-actin RNA from ribonuclease protection assays and TGF- $\alpha$ immunoreactivity on western blots were calculated using scanning laser densitom- 

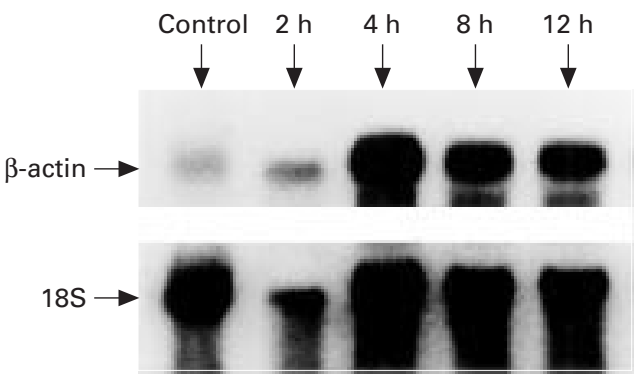

Figure 3: Comparison of $\beta$-actin and $18 r R N A$ expression before and at 2-12 hours after induction of colitis on northern blot analysis. A marked increase in $\beta$-actin $m R N A$ is seen during colitis.

etry (BioRad, Hercules, California, USA) with the integrated area expressed as the average of five individual determinations. The unpaired Student's $t$ test was used for comparison of the data and a $p$ value of $<0.05$ was considered significant.

\section{Results}

EXPERIMENTAL COLITIS

Irritation of the colonic mucosa with $50 \%$ ethanol in TNBS resulted in a severe inflammation that involved all layers of the colon. At 24 hours $80 \%$ of the exposed mucosa showed erosions but no ulcers were detected. Numerous inflammatory cells and severe tissue oedema were present in the colon. Myeloperoxidase activity expressed by neutrophil granulocytes and macrophages increased markedly within the first 24 hours (fig 1).

TGF- $\alpha$ and EGF $m R N A$ expression

Within the first two hours after mucosal injury TGF- $\alpha$ mRNA expression decreased significantly compared with uninflamed colon. At four and eight hours after induction of colitis TGF- $\alpha$ mRNA increased 3-4 times over the levels of uninflamed colon and returned to basal levels of TGF- $\alpha$ mRNA expression after 12-24 hours (fig 2). Northern blot analysis performed with poly-A RNA extracted from uninflamed and inflamed colon tissue revealed a $4.5 \mathrm{~kb}$ transcript known to encode TGF- $\alpha$ (data not shown).

$\beta$-actin mRNA expression in inflamed colonic tissue was also increased compared with uninflamed colonic tissue and was therefore

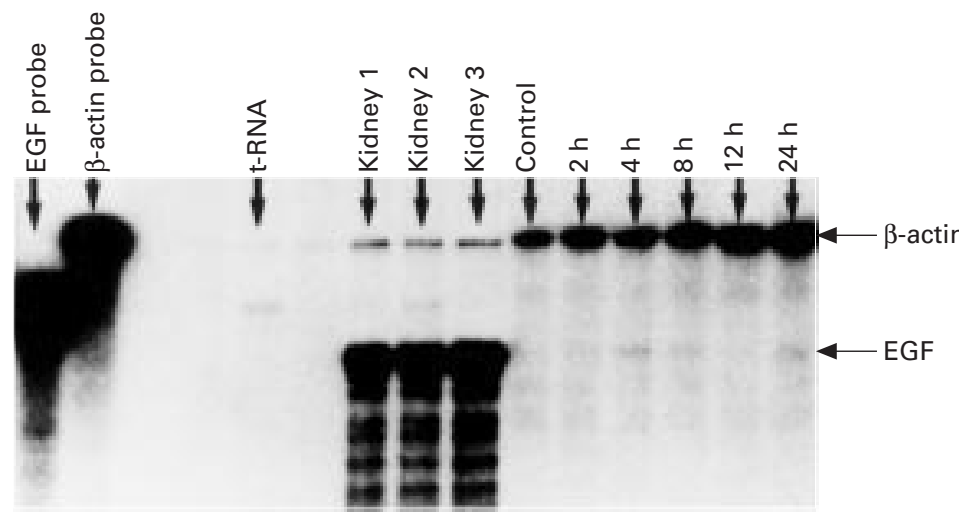

Figure 4: Nuclease protection assay analysing expression of EGF $m R N A$ in normal and inflamed colonic tissue. Weak protected bands were detected in both normal and inflamed tissue. Abundant EGF $m R N A$ was present in kidney extracts. not suitable as a housekeeping gene (fig 2). $18 \mathrm{~S}$ ribosomal RNA expression was comparable to uninflamed control colons at 4-12 hours, the time points when a marked increase in expression of $\beta$-actin mRNA was seen (fig 3). The pattern of $18 \mathrm{~S}$ rRNA and $\beta$-actin mRNA expression was observed consistently in our experiments, making it unlikely that differences in the amounts of total RNA used in the ribonuclease protection assays were responsible for the observed increase in the expression of TGF- $\alpha$. Increased expression of housekeeping genes in different experimental settings has also been described by others. ${ }^{32}$

Figure 4 shows the expression of EGF mRNA in normal and inflamed colonic tissue up to 24 hours after induction of the colitis. After prolonged exposure of the $x$-ray film weak protected bands of EGF mRNA became visible. No changes were detected before and after induction of colitis. Marked expression of EGF mRNA was detected in kidney extracts. Note that about 10 times less RNA isolated from kidney was used as a positive control to perform nuclease protection assays compared with RNA extracted from colonic tissues due to the expected high expression of EGF $\mathrm{mRNA}$ in the kidney. No EGF mRNA was detected on northern blots (data not shown).

\section{Immunohistochemistry for TGF- $\alpha$ and $E G F$}

Figure 5 shows TGF- $\alpha$-like immunoreactive staining in colonic tissue before and at different time points after mucosal injury. In uninflamed colon TGF- $\alpha$-like immunoreactivity was predominantly found in the upper half of the crypts and in the luminal surface epithelium (fig 5A). Within the first two hours after mucosal injury the upper half of the mucosa became necrotic and TGF- $\alpha$-like immunoreactive staining disappeared (fig 5B). Whereas some of the damaged areas remained necrotic and presumably will turn into ulcers, TGF- $\alpha-$ like immunoreactivity reappeared in remaining epithelial cells at the bottom of the crypts and in epithelial cells of areas adjacent to necrotic areas (fig 5C). Between 8 and 12 hours TGF$\alpha$-like immunoreactivity was detected in epithelial cells along the entire crypts (fig 5C) and in migrating epithelial cells (fig 5D). At 24 hours after induction of colitis TGF- $\alpha$-like immunoreactivity was again more pronounced in the upper half of the crypts (fig $5 \mathrm{E}$ ).

No differences between staining with the monoclonal anti-TGF- $\alpha$ antibody and polyclonal anti-TGF- $\alpha$ antibody were detected. The staining with both antibodies was completely abolished after overnight preabsorption of either antibody with excess rat TGF- $\alpha$ (figs $5 \mathrm{~F}$ and $\mathrm{G}$ ).

EGF-like immunoreactivity was not detected in either normal or inflamed colonic tissue.

Western blot analysis for $T G F-a$

Figure 6A shows a representative western blot of homogenates of control and inflamed colon. In every experiment standard rat $\mathrm{TGF}-\alpha$ was loaded in a separate lane (fig 6B). Figure 6C demonstrates the efficiency of the method used 

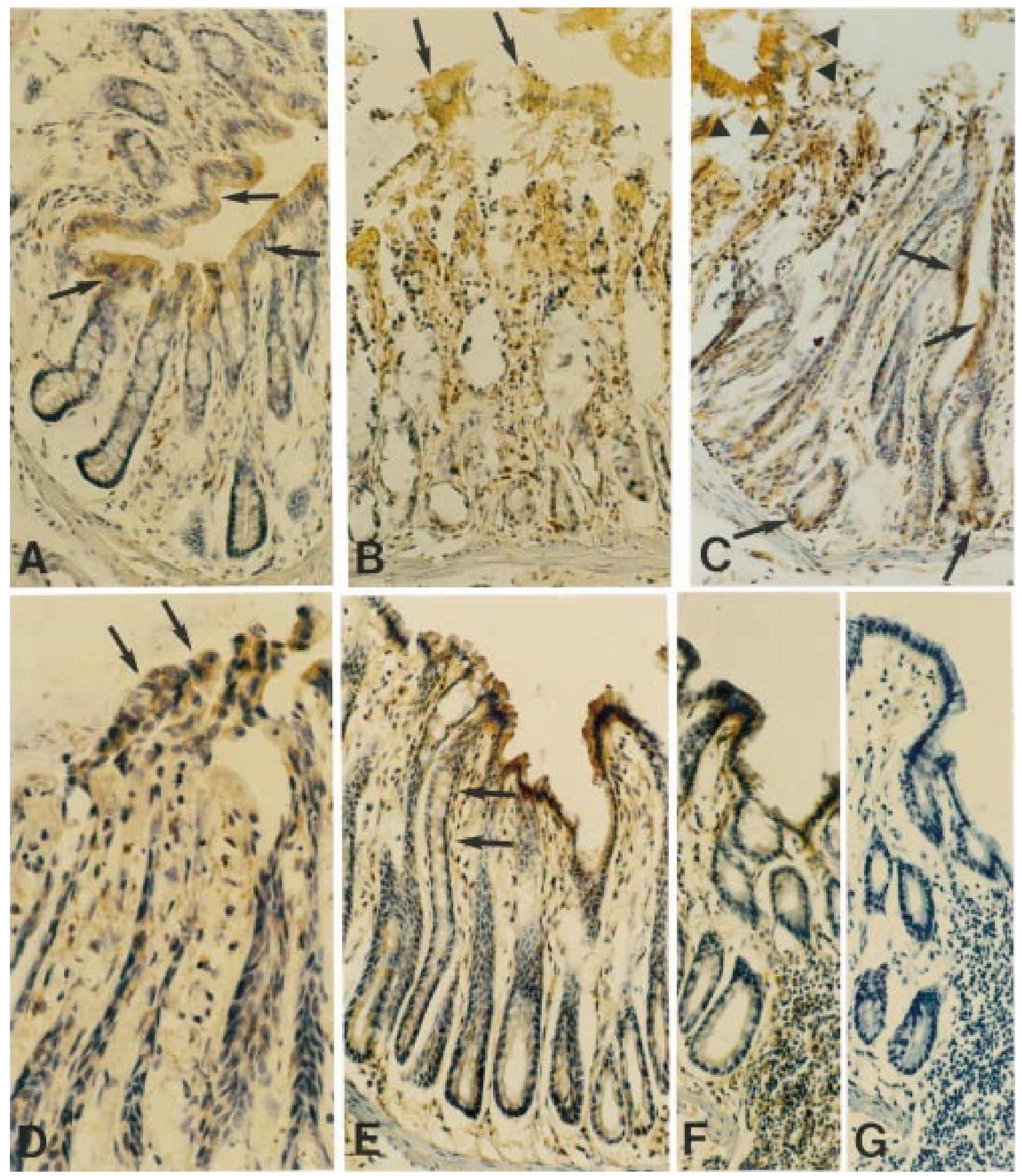

Figure 5: TGF-a-like immunoreactive staining in colonic tissue before and at different time points after mucosal injury. (A) In uninflamed colon TGF-a-like immunoreactivity was predominantly found in the upper half of the crypts and in the luminal surface epithelium. (B) Within the first two hours after mucosal injury the upper half of the mucosa became necrotic and TGF-a-like immunoreactive staining disappeared. (C) While some of the damaged areas remained necrotic and presumably will turn into ulcers, TGF-a-like immunoreactivity reappeared in remaining epithelial cells at the bottom of the crypts and in epithelial cells of areas adjacent to necrotic areas. Between 8 and 12 hours TGF-a-like immunoreactivity was detected in epithelial cells along the entire crypts (C) and in migrating epithelial cells (D). (E) Twenty four hours after induction of colitis TGF-a-like immunoreactivity was again more pronounced in the upper half of the crypts. $(F, G)$ The staining with both antibodies was completely abolished after overnight preabsorption of either antibody with excess rat TGF- $a$.

to detect $250 \mathrm{ng}$ synthesised rat TGF- $\alpha$. The majority of TGF- $\alpha$-like immunoreactivity was found in bands of about $28 \mathrm{kDa}$. A $5.6 \mathrm{kDa}$ band corresponding to mature TGF- $\alpha$ was not detected in either control or inflamed colon. Compared with uninflamed colon, TGF- $\alpha$-like immunoreactivity disappeared within two hours after induction of colitis but was increasingly expressed at 8-12 hours of inflammation. TGF- $\alpha$ levels returned to basal expression at 24 hours after induction of colitis. Figure 7 shows a comparison of the expression of TGF- $\alpha$ mRNA and TGF- $\alpha$-like immunoreactivity. As can be seen, expression of TGF- $\alpha$ 


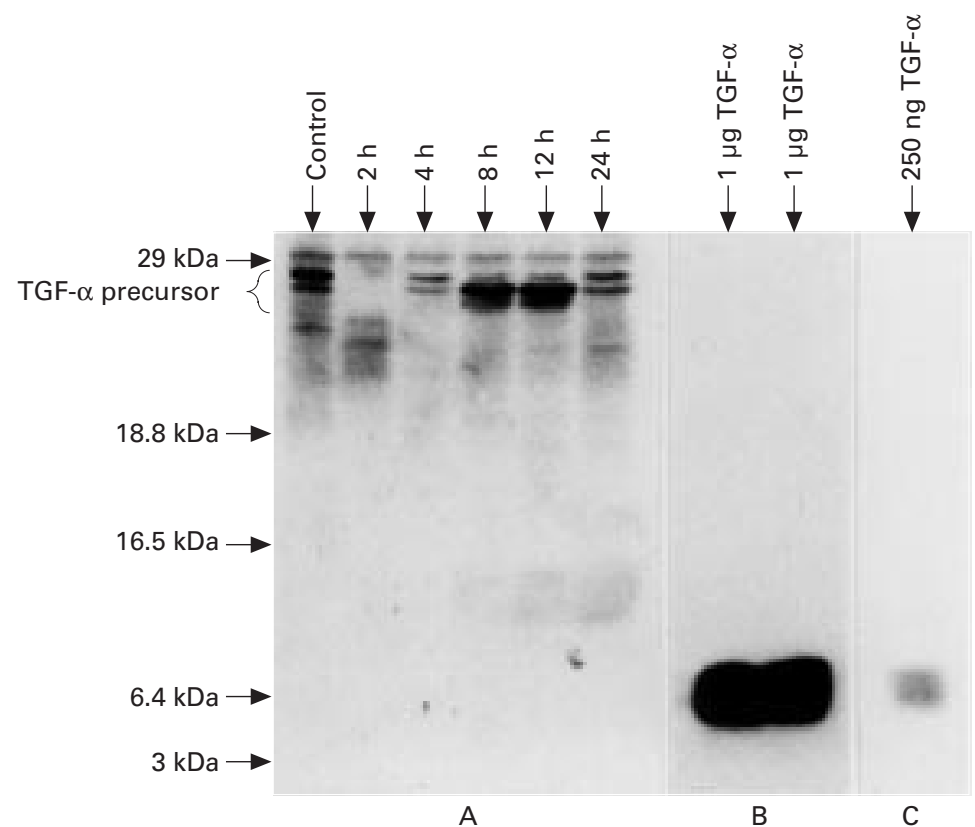

Figure 6: $\quad$ TGF-a protein expression on western blot analysis before and after induction of colitis. The same polyclonal antibody was used as for immunohistochemical analysis. No immunoreactive band was found in the molecular size of mature processed $5.6 \mathrm{kDa} T G F-a$. Immunoreactive bands were found with a higher molecular weight of about $28 \mathrm{kDa}$. Additional weak non-specific bands were seen which also appeared after incubation of corresponding blots with different non-immune rabbit sera.

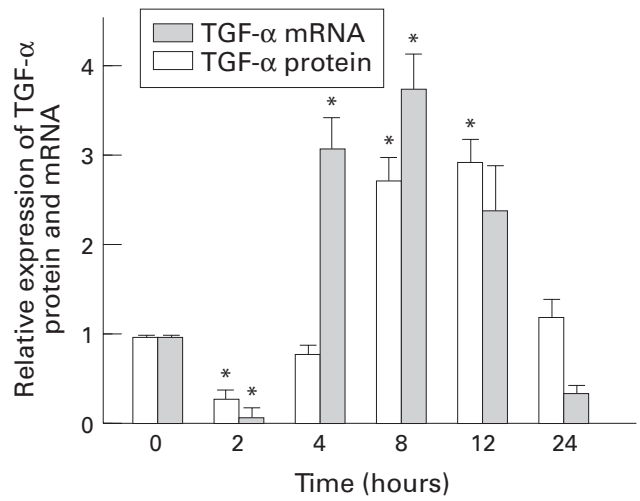

Figure 7: Comparison of TGF- $a$ protein $(n=6)$ and $m R N A(n=3)$ expression during the first 24 hours of colitis by western blot analysis and nuclease protection assays, respectively.

protein increased slightly later than $\mathrm{TGF}-\alpha$ mRNA during colitis.

No immunoreactive EGF was found by western blot analysis in tissue extracts of normal or inflamed colon.

\section{Discussion}

In response to acute mucosal injury expression of TGF- $\alpha$ mRNA and protein levels increased significantly. Although small amounts of EGF mRNA were detected on nuclease protection assays, no increase was seen during the course of colitis. Furthermore, no EGF protein was found by immunohistochemical or western blot analysis in the rat colon, suggesting that locally produced EGF is not a key component of mucosal repair after acute injury. Having shown previously that activation of the EGF receptors by exogenously administered EGF protected colonic mucosa against ethanol and TNBS induced injury, ${ }^{23}$ we now hypothesise that TGF- $\alpha$ is the locally expressed member of the EGF family that mediates the capability of EGF to maintain mucosal integrity and to accelerate restitution after injury. The importance of TGF- $\alpha$ in mucosal protection is supported by recent studies with mice deficient in TGF- $\alpha$ (waved 1 mice) where mucosal damage after application of oral dextran sulphate was significantly more pronounced in TGF- $\alpha$ deficient mice than in controls. ${ }^{33}$ Increased expression of TGF- $\alpha$, but not EGF, was also reported by Polk et al using experimental ulcer models in the rat stomach. ${ }^{34}$ Of interest, in the experimental stomach ulcer model as well as in our experimental model of colitis TGF- $\alpha$ expression increased early within six hours after injury, underlining the importance of endogenous TGF- $\alpha$ for mucosal protection and restitution. In contrast, Alison et $a l^{35}$ found an abundant expression of both EGF and TGF- $\alpha$ in rat stomach tissue and an increased and prolonged expression of both EGF and TGF- $\alpha$ after cryoprobe induced injury. In this experimental setting EGF expression was increased from days 1-10 after induction of injury and TGF- $\alpha$ expression was increased from day 6 after injury. It is therefore possible that EGF and TGF- $\alpha$ are expressed simultaneously in the rat stomach and that the pattern of TGF- $\alpha$ expression is dependent on the way mucosal injury is induced and the additional expression of EGF. We cannot exclude the possibility that, in the colon, other members of the EGF family such as amphiregulin $^{3}$ and heparin-binding epidermal growth factor ${ }^{2}$ participate in the mucosal response to injury. It is also possible that luminal EGF may play an additional role in protecting or healing colonic mucosa after injury.

Although we do not have direct evidence from the present study for a TGF- $\alpha$ induced biological effect, the mechanisms of action of TGF- $\alpha$ could involve mucus production and release in response to injury, ${ }^{20}$ induction of TGF- $\beta$ expression leading to cell migration and epithelial cell restitution, ${ }^{17}$ increase in prostaglandin production, ${ }^{36}$ inhibition of inducible nitric oxide synthase leading to diminished NO production, ${ }^{37}$ increased mucosal blood flow, ${ }^{18}$ and cell proliferation and differentiation. ${ }^{1}$ This is a matter for further study.

Wright $e t a l^{2}$ reported an increase in EGF immunoreactivity in humans that was associated with a cell lineage involved in the repair of chronic ulcerations in the stomach and intestine of patients with peptic ulcer and inflammatory bowel disease. These findings support the hypothesis that EGF family peptides are important in mucosal repair. It is possible that in humans EGF, and not TGF- $\alpha$, is the key mediator of mucosal repair in response to injury. However, it will be interesting to study concomitantly the expression of different EGF family members' mRNA and protein levels in patients with gastrointestinal ulcerations to characterise further the interactions of the peptides of the EGF family. To our knowledge our study is the first to combine these 
techniques to characterise EGF/TGF- $\alpha$ expression in response to mucosal injury.

Of interest was our observation that the TGF- $\alpha$ precursors are not metabolised into the mature soluble $5.6 \mathrm{kDa}$ TGF- $\alpha$ protein after injury. This suggests that in rat colonic mucosa the biological action of TGF- $\alpha$ peptides is mediated by large TGF- $\alpha$ molecules produced by epithelial cells. These molecular forms could still be membrane anchored and act locally on the same or adjacent cells, favouring the assumption of an autocrine or juxtacrine pathway. In fact, it has been shown that soluble and membrane bound TGF- $\alpha$ precursors are biologically active by binding and activating the EGF receptor on adjacent cells in vitro. ${ }^{15}$ Another explanation for the fact that no mature processed $5.6 \mathrm{kDa}$ TGF- $\alpha$ was detected in our experiments could be that the $5.6 \mathrm{kDa}$ TGF- $\alpha$ metabolite was rapidly removed into the lumen after cleavage from the precursor. However, when the luminal content of inflamed colon at 8 or 12 hours was homogenised and subjected to western blot analysis only the larger molecular forms, but no $5.6 \mathrm{kDa}$ TGF- $\alpha$, were present (data not shown). Our finding that TGF- $\alpha$ precursors are the predominant molecular forms of TGF- $\alpha$ in the inflamed intestine is supported by a recent report in human fetal intestine where only TGF- $\alpha$ precursors with molecular weights of 30 and $68 \mathrm{kDa}$ - and not the $5.6 \mathrm{kDa}$ TGF- $\alpha$-were found on western blot analysis in intestinal extracts. ${ }^{38}$ Our report is the first to show that, after acute mucosal injury, TGF- $\alpha$ precursors, and no mature 5.6 $\mathrm{kDa}$ TGF- $\alpha$ protein, were found. Our data strongly support the hypothesis that the biological activity of TGF- $\alpha$ is mediated by TGF- $\alpha$ precursors.

In uninflamed colonic mucosa TGF- $\alpha$ is expressed predominantly in epithelial cells in the upper half of the crypts and in epithelial cells of the luminal surface. In response to injury these surface cells became necrotic and were shed into the lumen. At this time TGF- $\alpha$ protein and mRNA expression fell markedly as assessed by nuclease protection assay and western blot analysis. At 8 and 12 hours of inflammation, when peak expression of TGF- $\alpha$ mRNA and protein was obtained, TGF- $\alpha$ was localised in the remaining intact epithelial cells of the crypts and in entire crypts in areas adjacent to the damaged mucosa. With restoration of the mucosal integrity TGF- $\alpha$ expression was again predominantly found in cells in the upper half of the crypts and the surface epithelium and TGF- $\alpha$ expression returned to levels of uninflamed colon.

The signal for the upregulation of TGF- $\alpha$ in response to mucosal injury is unknown. Increased TGF- $\alpha$ gene expression occurred within 4 and 6 hours and prior to the maximum influx of inflammatory cells, suggesting that mucosal injury by itself-and not mediators released from inflammatory cells, especially neutrophils - are responsible for this effect.

In summary, the marked expression of TGF- $\alpha$ on the levels of mRNA and protein early after mucosal injury suggests a pivotal role for TGF- $\alpha$ within the kindred of the EGF family responsible for mucosal protection and restitution. Detection of TGF- $\alpha$ precursors and not of the fully processed $5.6 \mathrm{kDa}$ TGF- $\alpha$ protein in response to injury indicates that soluble and/or membrane bound TGF- $\alpha$ precursors mediate the actions of TGF- $\alpha$ and thus favour the assumption of an autocrine or juxtacrine pathway.

This study was supported by the Harbor-UCLA Inflammatory Bowel Disease Center and by Deutsche Forschungsgemeinschaft (DFG) (Ho1477/1-1).

1 Carpenter G, Cohen S. Epidermal growth factor. Ann Rev Biochem 1979; 48: 193-216.

2 Higashiyama S, Abraham JA, Miller J, Fiddes JC, Klagsbrun M. A heparin-binding growth factor secreted by macrophage-like cells that is related to EGF. Science 1991; 251: $936-9$.

3 Shoyab M, Plowman GD, McDonald VL, Bradley JG, Todaro GJ. Structure and function of human amphiregulin: a member of the epidermal growth factor family. Science 1989; 243: 1074-6.

4 DeLarco JE, Todaro GJ. Growth factors from murine sarcoma virus-transformed cells. Proc Natl Acad Sci USA 1978; 75: 4001-5.

5 Cartlidge SA, Elder JB. Transforming growth factor alpha and epidermal growth factor levels in normal human gastrointestinal mucosa. Br f Cancer 1989; 60: 657-60.

6 Miettinen PJ, Perheentupa J, Otonkoski T, Lahteenmaki A, Panula P. EGF- and TGF-alpha-like peptides in human fetal gut. Pediatr Res 1989; 26: 25-30.

7 Schaudies RP, Grimes J, Davis D, Rao RK, Koldovsky O. EGF content in the gastrointestinal tract of rats: effect of age and fasting/feeding. Am f Physiol 1989; 256: G856-61.

8 Perez-Tomas R, Cullere X, Diaz C. Immunohistochemical localization of transforming growth factor alpha in the developing rat colon. Gastroenterology 1993; 104: 789-95.

9 Marquardt H, Hunkapiller MW, Hood LE, Todaro GJ. Rat transforming growth factor type 1: structure and relation to epidermal growth factor. Science 1984; 223: 1079-82.

10 Mroczkowski B, Reich M, Chen K, Bell GI, Cohen S. Recombinant human epidermal growth factor precursor is glycosilated membrane protein with biological activity. Mol Cell Biol 1989; 9: 2771-8.

11 Bringman TS, Lindquist PB, Derynck R. Different transforming growth factor alpha species are derived from a glycosylated and palmoylated transmembrane precursor. Cell 1987; 48: 429-40.

12 Linsley PS, Hargraves WR, Twardzik DR, Todaro GJ. Detection of larger polypeptides structurally and functionally related to type I transforming growth factor. Proc Natl Acad Sci USA 1985; 82: 356-60.

13 Teixido J, Gilmore R, Lee DC, Massague J. Integral membrane glycoprotein properties of prohormone protransforming growth factor alpha. Nature 1987; 326: $883-5$.

14 Bosenberg MW, Pandiella A, Massaguë J. The cytoplasmic carboxy-terminal amino acid specifies cleavage of membrane TGF alpha into soluble growth factor. Cell 1992; 71: brane TG.

15 Wong ST, Winchell LF, McCune BK, Earp HS, Teixido J, Massague J, et al. The TGF-alpha precursor expressed on the cell surface binds to the EGF receptor on adjacent cells, leading to signal transduction. Cell 1989; 56: 495-506.

16 Al-Nafussi AI, Wright NA. The effect of epidermal growth factor (EGF) on cell proliferation of the gastrointestinal mucosa in rodents. Virchows Arch B Cell Pathol 1982; 40: 63-9.

17 Dignass AU, Podolsky DK. Cytokine modulation of intestinal epithelial cell restitution: central role of transforming growth factor beta. Gastroenterology 1993; 105: 1323-32.

18 Hui WM, Chen BW, Kung ACW, Cho CH, Luk CT, Lam SK. Effect of epidermal growth factor on gastric blood flow in rats: possible role in mucosal protection. Gastroenterology 1993; 104: 1605-10.

19 McLeay LM, Comeskey MA, Waters MJ. Effects of epidermal growth factor on gastrointestinal electromyographic mal growth factor on gastrointestinal electromyographic

20 Kelly SM, Hunter O. Epidermal growth factor stimulates synthesis and secretion of mucus glycoproteins in human gastric mucosa. Clin Sci 1990; 79: 425-7.

21 Rhodes JA, Tam JP, Finke M, Saunders J, Bernanke J, Silen $\mathrm{W}$, et al. Transforming growth factor alpha inhibits secretion of gastric acid. Proc Natl Acad Sci USA 1986; 83: 3844-6.

22 Wright NA, Pike C, Elia G. Induction of a novel epidermal growth factor-secreting cell lineage by mucosal ulceration in human gastrointestinal stem cells. Nature 1990; 343: $82-5$.

23 Procaccino F, Reinshagen M, Hoffmann P, Zeeh JM, Lakshmanan J, McRoberts JA, et al. Protective effect of epidermal growth factor in an experimental model of coliepidermal growth factor in an experimental

24 Krawisz JE, Sharon P, Stenson WF. Quantitative assay for acute intestinal inflammation based on myeloperoxidse activity. Assessment of inflammation in rat and hamster models. Gastroenterology 1984; 87: 1344-50. 
25 Lee DC, Rose TM, Webb NR, Todaro GJ. Cloning and sequencing of a CDNA for rat transforming growth factor sequencing of a cDNA for rat tr
alpha. Nature 1985; 313: 489-91.

26 Saggi SJ, Safirstein R, Price PM. Cloning and sequencing of the rat preproepidermal growth factor CDNA: comparison with mouse and human sequences. DNA Cell Biol 1992; 11 $481-7$

27 Chromczynski P, Sacchi N. Single-step method of RNA isolation by acid guanidinium thiocyanate-phenol-chloroform extraction. Anal Biochem 1987; 162: 156-9.

28 Zanconato S, Moromisato DY, Moromisato MY, Woods J, Brasel JA, Leroith D, et al. Effect of training and growth hormone suppression on insulin-like growth factor mRNA in young rats. F Appl Physiol 1994; 76: 2204-9.

29 Zamboni L, DeMartino C. Buffered picric-acid formaldehyde: a new rapid fixative for electron microscopy [abstract]. F Cell Biol 1967; 35: 148A.

$30 \mathrm{Liu} \mathrm{L}$, Barajas L. The rat renal nerves during development. Anat Embryol 1993; 188: 345-61.

31 Laemmli UK. Cleavage of structural proteins during the assembly of the head of bacteriophage T4. Nature 1970; 227: $680-5$.

32 Campbell ZW, Yamada T. Effect of omeprazole on gene expression in gastric parietal cells. Am F Physiol 1991; 260 G434-9.
33 Eysselein VE, Procaccino F, Reinshagen M, Hoffmann P, Patel A, Reuben W, et al. Mice deficient in transforming growth factor-alpha (WA-1) are highly susceptible to dextran sulfate colitis [abstract]. Gastroenterology 1996; 108: A906.

34 Polk WH Jr, Dempsey PJ, Russell WE, Brown PI, Beauchamp RD, Barnard JA, Coffey RJ Jr. Increased roduction of transforming growth factor alpha following acute gastric injury. Gastroenterology 1992; 102: 1467-74.

35 Alison MR, Chinery R, Poulsom R, Ashwood P, Longcroft JM, Wright NA. Experimental ulceration leads to sequential expression of spasmolytic polypeptide, intestinal trefoil factor, epidermal growth factor and transforming growth factor alpha mRNAs in rat stomach. F Pathol 1995; 175: 405-14

36 Mitchell MD. Epidermal growth factor actions on arachidonic acid metabolism in human amnion cells. Biochim Biophys Acta 1987; 928: 240-2.

37 Heck DE, Laskin DL, Gardner CR, Laskin JD. Epidermal growth factor suppresses nitric oxide and hydrogen peroxide production by keratinocytes. 7 Biol Chem 1992; 267: ide productio

38 Miettinen PJ. Transforming growth factor-alpha and epidermal growth factor expression in human fetal gastrointestinal tract. Pediatr Res 1993; 33: 481-6. 